\title{
PENGEMBANGAN SEKTOR PEMASARAN SEBAGAI DUKUNGAN TERHADAP PROGRAM INDUSTRIALISASI PERIKANAN (Studi Kasus: Komoditas Nila di Kabupaten Musi Rawas Propinsi Sumatera Selatan)
}

\section{Marketing Sector Development As A Support For Fisheries Industrialization Program (Case Study: Tilapia Fish in the Musi Rawas Regency, South Sumatera)}

\author{
"Hertria Maharani dan Rani Hafsaridewi \\ Balai Besar Penelitian Sosial Ekonomi Kelautan dan Perikanan \\ Gedung Balitbang KP I Lt. 4 \\ Jalan Pasir Putih Nomor 1 Ancol Timur, Jakarta Utara \\ Telp: (021) 64711583 Fax: 64700924 \\ "email: hertria.maharani@gmail.com \\ Diterima 28 Februari 2014 - Disetujui 6 Juni 2014
}

\begin{abstract}
ABSTRAK
Industrialisasi perikanan yang dicanangkan oleh Kementerian Kelautan dan Perikanan bertujuan untuk meningkatkan produksi, produktivitas dan nilai tambah produk kelautan dan perikanan yang berdaya saing tinggi. Peningkatan produksi yang tanpa disertai oleh upaya meningkatkan pemasaran akan berdampak pada kurang berhasilnya program tersebut. Penelitian ini mengkaji usaha budidaya, pasar, saluran pemasaran dan perdagangan ikan nila yang berasal dari Kabupaten Musi Rawas, Propinsi Sumatera Selatan. Studi lapangan dilakukan pada Bulan Maret-Juni 2012. Instrumen utama yang digunakan dalam penelitian ini adalah metode survey dengan bantuan kuesioner dan wawancara mendalam dengan informan kunci. Responden terdiri dari pembudidaya, pengumpul, pedagang serta penentu kebijakan yang terkait dengan komoditas ikan nila. Metode analisis dilakukan secara analisis deskriptif. Hasil penelitian menunjukkan bahwa meskipun terdapat peningkatan produksi budidaya ikan nila, namun pemasaran ikan terbatas pada pasar lokal. Pihak pembudidaya masih menjadi pihak price taker yang artinya tidak dapat meningkatkan posisi tawarnya. Struktur pasar pembudidaya bersifat persaingan sempurna, pada sisi lain dengan struktur pedagang bersifat oligopsoni sehingga harga di tingkat pembudidaya berada dibawah pengendalian pedagang. Untuk meningkatkan kesejahteraan petani budidaya, dibutuhkan upaya menghilangkan pola patron-client dalam pembiayaan usaha dan pengembangan jalur pemasaran baru perlu dilakukan seperti dengan mencari pelanggan untuk keperluan restoran ataupun melakukan pemasaran ikan nila hingga ke daerah lain.
\end{abstract}

Kata Kunci: pemasaran, ikan nila, price taker, oligopsoni

\begin{abstract}
Fisheries industrialization were announced by the Ministry of Marineand FisheriesAffairs aims to increase production, productivity and value-added of fishery products. But of course, increased production without increasing marketing efforts will makeless successful impact for the program. This research will examine aquaculture bussiness, market, marketing channel and trading of tilapia from Musi Rawas Regency, South Sumatra Province. Field studies conducted in March until June 2012. The main instrument of this study using a survey method with questionnaires and in-depth interviews with key informants. Respondents were consist of farmers, fish collectors, traders and policy makers related tilapia. Methods of analysis conducted with descriptive analysis. Results study showed that despite an increase in production experienced by farmers, but commodities marketed limited to the local market. Fish farmer is still as price takers meaning it cannot increasing their bargaining power. The structure of farmers markets are perfectly competitive, on the other hand the structure of merchanct is oligopsonistic. So the prices at the farmers level are controlled by merchants. To improve the welfare of fish farmers, it should diminish patron client relationship and develop a new marketing channels, such as searching customer for restaurant or marketing tilapia to another region.
\end{abstract}

Keywords: marketing, tilapia fish, price taker, oligopsony 


\section{PENDAHULUAN}

Kementerian Kelautan dan Perikanan (KKP) pada tahun 2011 telah mengeluarkan program industrialisasi perikanan yang salah satu tujuannya adalah meningkatkan produksi, produktivitas dan nilai tambah produk kelautan dan perikanan yang berdaya saing tinggi. Program ini sesuai dengan visi KKP yang ingin menjadikan Indonesia sebagai penghasil produk kelautan dan perikanan terbesar pada tahun 2015.

Untuk mewujudkan visi tersebut tersebut, Kementerian Kelautan dan Perikanan (KKP) saat ini mengenjot sektor budidaya melalui industrialisasi perikanan dengan mengusung ikan nila sebagai salah satu komoditas unggulan. Nila menjadi komoditas unggulan karena komoditas ini mengalami peningkatan permintaan dari tahun ke tahun, baik dari pasar domestik maupun internasional. Setengah dari impor ikan nila di Amerika Serikat dipasok oleh Cina, sedangkan sisanya oleh Taiwan, Thailand dan Indonesia (Kementerian Kelautan dan Perikanan, 2012). Produksi nila nasional pada tahun 2001 sebesar 34.122 ton, dan kemudian meningkat menjadi sebesar 214.514 ton pada tahun 2010 (Khairuman dan Amri, 2011). Peningkatan produksi menjadikan Indonesia sebagai peringkat keempat negara produsen nila terbesar di dunia setelah Cina, Mesir dan Filipina. Hingga saat ini sekitar $80 \%$ produksi ikan Nila masih diserap pasar lokal (Iriana, 2009).

Selain permintaan yang tinggi, alasan kedua ikan nila dijadikan sebagai komoditas unggulan adalah resistensi ikan tersebut terhadap berbagai virus karena, ikan nila memiliki daya tahan terhadap penyakit yang lebih kuat. Keunggulan ini membuat para pembudidaya bersemangat untuk memproduksi komiditas nila. Produksi ikan nila yang terus bertambah setiap tahunnya memberikan potensi dan harapan yang cerah untuk terus dikembangkan. Potensi yang besar ini juga dimiliki oleh Propinsi Sumatera Selatan. Propinsi Sumatera Selatan merupakan sentra budidaya ikan nila terbesar kedua secara nasional. Pada tahun 2010, produksi nila propinsi ini mencapa 16,82\% dari total produksi nasional.

Peningkatan produksi yang diprioritaskan dalam program industrialisasi perikanan, tentunya juga harus diimbangi dengan kesiapan aspek pemasaran. Sebelum melakukan usaha, seorang pengusaha sebaiknya berpikir dan berorientasi ke aspek pemasaran terlebih dahulu (Dardiani dan Intan, 2010). Tanpa adanya saluran pemasaran yang baik peningkatan produksi justru dapat menjadi bumerang bagi produsen dalam hal ini para pembudidaya. Banyak contoh kasus di daerah, seperti yang diungkapkan oleh Dinas Kelautan dan Perikanan Propinsi Kalimantan Selatan bahwa Kabupaten Banjar tahun ini sedang mengalami kelebihan produksi sebanyak 2.000 ton untuk komoditas patin. Patin yang sudah diproduksi tidak dapat seluruhnya terserap oleh pasar dengan berbagai alasan. Hal ini salah satunya ditenggarai oleh saluran pemasaran yang kurang baik sehingga menyumbat rantai pasok dari komoditas itu sendiri. Terdapat juga contoh kasus kelebihan produksi yang mengakibatkan turunnya harga komoditas secara drastis yang terjadi di Kabupaten Jambi pada tahun 2010. Pada saat itu, peningkatan produksi secara bersamaaan tidak diimbangi dengan serapan pasar sehingga banyak pembudidaya yang menjual hasil budidaya mereka dengan harga yang rendah. Oleh karena itu, aspek pemasaran merupakan bagian yang penting untuk dikaji.

Produksi yang terus meningkat di sektor hulu, akan menjadi lebih baik jika usaha budidaya ikan nila juga didukung dengan sistem pemasaran yang baik pada sektor hilir. Hal ini selain diharapkan untuk mempercepat tercapainya industrialisasi perikanan, juga dapat meningkatkan pendapatan pembudidaya sehingga kesejahteraan dapat meningkat.

Sampai saat ini banyak komoditas nila yang tidak dapat dipasarkan dengan baik karena memiliki saluran pemasaran yang terbatas atau rantai pemasaran yang cukup panjang sehingga pembudidaya menerima sedikit sekali keuntungan dari penjualan ikan nila. Untuk itu cukup penting kiranya untuk dilakukan kajian terhadap sektor hilir dari komoditas ini. Berdasarkan hal tersebut penting untuk dikaji perkembangan usaha budidaya ikan nila, pola perdagangan komoditas nila dan saluran pemasaran komoditas nila. Dalam saluran pemasaran penting juga untuk ditelusuri saluran yang paling memberikan pendapatan tertinggi bagi pembudidaya. Dari kajian tersebut akan dapat terlihat tujuan penelitian yaitu identifikasi perkembangan usaha budidaya komoditas nila, analisa pola perdagangan yang terjadi pada komoditas ikan nila dan analisa saluran pemasaran yang efektif dan paling menguntungkan bagi pembudidaya nila. 


\section{METODOLOGI}

Penelitian ini dilakukan di Kabupaten Musi Rawas Propinsi Sumatera Selatan. Kegiatan pengumpulan data primer dan sekunder dilakukan pada Bulan Maret- Juni 2012. Cara pengumpulan data adalah dengan melakukan survey dan wawancara mendalam dengan bantuan kuesioner. Wawancara dilakukan kepada responden 30 orang. Pengambilan sampel dilakukan, secara purposive yang terdiri dari pelaku usaha pembudidaya, pengumpul, pedagang serta penentu kebijakan terkait ikan nila yang berada di sentra produksi ikan nila di lokasi penelitian. Metode analisis dilakukan secara deskriptif. Selanjutnya, guna menghitung margin pemasaran maka, digunakan formulasi berikut (Anwar,1994) :

$$
M=H p-H b
$$

Dimana:

$\mathrm{M}=$ Margin pemasaran/Marketing margin

$\mathrm{Hp}=$ Harga penjualan/selling price

$\mathrm{Hb}=$ Harga beli/buying price

Untuk menghitung keuntungan dari masingmasing lembaga pemasaran digunakan rumus :

$\pi=M-B p$

Dimana :

$\boldsymbol{\pi}=$ Keuntungan pemasaran/marketing profit

$M=$ Margin pemasaran/marketing margin

$\mathrm{Bp}=$ Biaya pemasaran/marketing cost
Sedangkan menurut Dahl dan Hammond (1977) untuk mengetahui struktur pasar, digunakan analisis sistem pemasaran yang mengkaji struktur pasar (structure), tingkah laku pasar (conduct), dan keragaan pasar (performance).

\section{HASIL DAN PEMBAHASAN}

\section{Usaha Budidaya}

Di antara jenis ikan budidaya perairan tawar, ikan nila merupakan salah satu komoditas andalan yang dapat dikembangkan untuk pasar dalam negeri maupun ekspor. Jenis ikan ini bahkan dapat dipelihara di perairan payau. Ikan nila mempunyai ciri-ciri yang diinginkan untuk komoditas budidaya yaitu cepat dari segi pertumbuhan, sedikit tulang, rasa daging yang enak, mudah berkembang biak, pasar yang baik dan mampu beradaptasi dengan kisaran yang lebar dari kondisi lingkungan (Pondaag, 2010). Dengan berbagai pertimbangan tersebut, ikan nila dijadikan sebagai salah satu komoditas unggulan yang masuk dalam program industrialisasi perikanan KKP.

Selain itu, peningkatan permintaan ikan nila sebagai salah satu pilihan sumber protein hewani dengan harga yang terjangkau untuk masyarakat di negara berkembang seperti Indonesia, serta di pasar internasional juga ikut mendorong meningkatnya usaha budidaya ikan nila. Seperti yang telah dijelaskan, pemasok utama untuk komoditas ikan nila di Amerika adalah Cina, Taiwan, Thailand dan Indonesia. Jika dilihat dari produksi, Indonesia merupakan negara keempat penghasil ikan nila di dunia setelah Cina, Mesir dan Filipina.

Tabel 1. Produksi Nila Berdasarkan Sentra Produksi Nila di Indonesia Tahun 2010.

Table 1. Tilapia Production Based on Tilapia Production Center in Indonesia, 2010.

\begin{tabular}{clcc}
\hline & & Propinsi/Province & \multicolumn{2}{c}{ Produksi Nila/Tilapia Production } \\
\cline { 3 - 4 } No & & $\begin{array}{c}\text { Volume/Volume } \\
\text { (ton) }\end{array}$ & $\begin{array}{c}\text { Persentase/Percentage } \\
\text { (\%) }\end{array}$ \\
\hline 1 & Jawa Barat/West Java & 106,889 & 23.03 \\
2 & Sumatera Selatan/South Sumatera & 78,073 & 16.82 \\
3 & Sumatera Utara/North Sumatera & 60,852 & 13.11 \\
4 & Sumatera Barat/West Sumatera & 42,572 & 9.17 \\
5 & Jawa Tengah/Center Java & 28,715 & 6.19 \\
6 & Kalimantan Selatan/ South Kalimantan & 24,834 & 5.35 \\
7 & Jawa Timur/East Java & 23,211 & 5.00 \\
8 & Sulawesi Utara/North Sulawesi & 16,253 & 3.50 \\
9 & Jambi/Jambi & 12,267 & 2.64 \\
10 & Bengkulu/Bengkulu & 10,103 & 2.18
\end{tabular}

Sumber: Kementerian Kelautan dan Perikanan, 2010 / Source: Ministry of Marine and fisheries, 2010 
Keberhasilan dari budidaya nila ini tersebar di seluruh daerah di Indonesia dan membentuk sentra-sentra produksi nila.Untuk lokasi atau sentra produksi nila terbesar di Indonesia terletak di Propinsi Jawa Barat. Selain Propinsi Jawa Barat, sentra produksi Nila berada di Propinsi Sumatera Selatan. Produksi Nila di Jawa Barat sebesar 106.889 ton sedangkan untuk produksi nila di Sumatera Selatan sebesar 78.073 ton. Produksi Nila berdasarkan sentra produksi di Indonesia dapat dilihat pada Tabel 1.

Propinsi Sumatera Selatan, yang menjadi lokasi penelitian, merupakan produsen ikan nila terbesar kedua di Indonesia. Produksi ikan nila di Propinsi Sumatera Selatan dengan menggunakan sistem budidaya kolam air deras ini diharapkan terus meningkat. Jumlah produksi ikan nila pada tahun 2010 yaitu sebesar 48.056 ton. Jumlah ini menguasai $16,82 \%$ produksi nasional komoditas ikan nila. Berikut adalah grafik yang menampilkan jumlah produksi nila propinsi Sumatera Selatan dari Tahun 2001-2010'12.
Di Propinsi Sumatera Selatan, intensifikasi budidaya ikan nila berlangsung cepat sehingga ikan nila tidak hanya dipelihara di kolam seperti yang umum dilakukan, tetapi banyak juga yang menggunakan Keramba Jaring Apung (KJA) di waduk atau danau, karamba, sawah, kolam air deras, bahkan tambak air payau. Pada Kabupaten Musi Rawas, pengembangan budidaya ikan nila didukung oleh sarana jaringan irigrasi yang menyediakan sumber air tawar sepanjang tahun. Adanya jaringan irigrasi ini merupakan peluang untuk dapat meningkatkan produktivitas dari budidaya ikan nila di Propinsi Sumatera Selatan. Adapun jaringan irigrasi yang tersedia dapat dilihat pada Tabel 2.

Di Kabupaten Musi Rawas, Kecamatan Tugumulyo merupakan kecamatan terbesar penghasil ikan nila yaitu sekitar 6.125 ton pada tahun 2011 dengan mengandalkan jaringan irigasi yang ada. Dalam penelitian ini, lokasi yang dipilih adalah Kecamatan Muara Beliti (Kelurahan Priok,Ketuan Jaya, Air Satan), Kecamatan Tugu

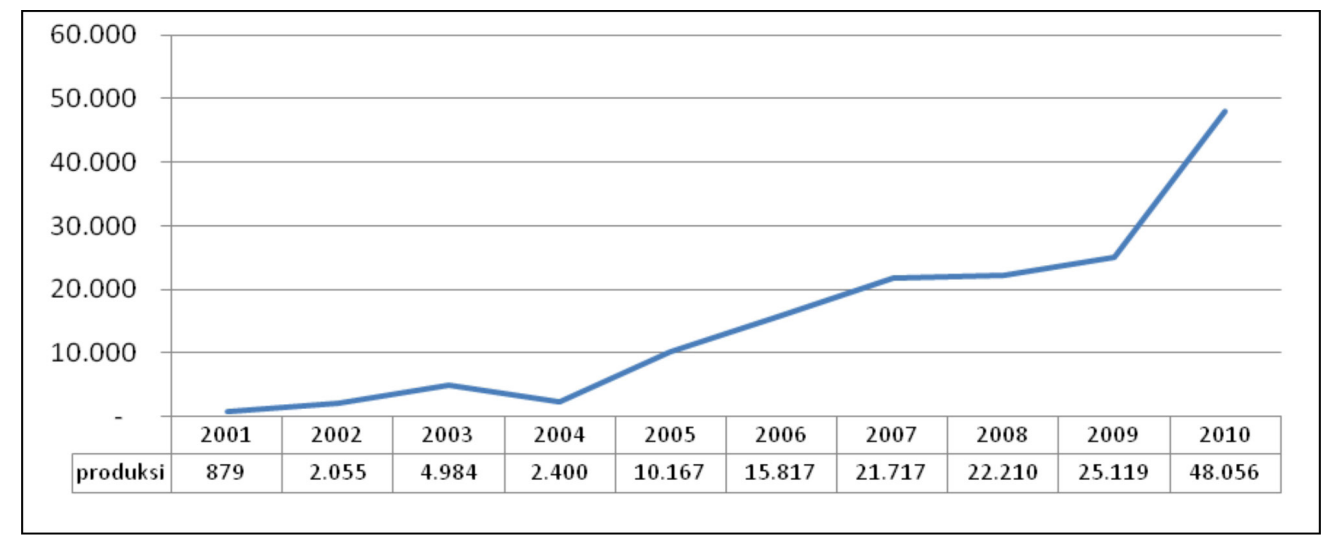

Gambar 1. Produksi Ikan Nila di Propinsi Sumatera Selatan (ton), Tahun 2010

Figure 1. Tilapia Production in South Sumatra Province (Ton), 2010

Sumber: Dinas Propinsi Sumatera Selatan, 2010/Source: South Sumatera Provincial Agency, 2010

Tabel 2. Jaringan Irigasi di Kabupaten Musi Rawas, Propinsi Sumatera Selatan. Table 2. Irigation Network in the Musi Rawas Regency, South Sumatera.

\begin{tabular}{clc} 
No & \multicolumn{1}{c}{ Irigasi/ Irigattion } & $\begin{array}{c}\text { Kemampuan Pengairan/ } \\
\text { Ability of Irigattion (Ha) }\end{array}$ \\
\hline 1 & Kelingi Tugumulyo & 36,000 \\
2 & Selangit Terawas & 15,000 \\
3 & Kali Deres Babat & 5,000 \\
4 & Jaya Loka & 3,000 \\
5 & Pagar Sari (Megang Tikip) & 2,000 \\
\hline
\end{tabular}

Sumber: Dinas Kelautan dan Perikanan Propinsi Sumatera Selatan, 2011/

Source: Fisheries and Marine Official Agency of South Sumatera Province, 2011 
Mulyo (Tegal Redjo, Ketuan I), Kecamatan Purwodadi (Mardihardjo). Hal ini dikarenakan kecamatan-kecamatan tersebut merupakan penghasil nila dengan jumlah yang besar dalam kabupaten.

Berdasarkan hasil karakteristik responden, usaha budidaya ikan nila ini telah lama menjadi mata pencaharian masyarakat di Musi Rawas. Pembudidaya yang ada di Kabupaten Musi Rawas mayoritas memiliki pengalaman usaha 1-5 tahun. Karakteristik pembudidaya di Kabupaten Musi Rawas terlihat pada Tabel 3.

Sebagian besar pembudidaya yaitu sebanyak $57,1 \%$ berada pada kelompok kisaran umur produktif yaitu umur 19 hingga umur 49 tahun. Usia produktif akan memudahkan pengenalan terhadap inovasi dan teknologi untuk kelompok pembudidaya. Terlebih lagi sebanyak 39,5\% pembudidaya minimal tamatan SD yang artinya dapat membaca dan menulis. B erda sarka n kesukuan, sebanyak $85,7 \%$ pembudidaya di Kabupaten Musi Rawas adalah transmigran dari Jawa. Secara aspek sosiologis, program-program yang dilakukan oleh pemerintah harusnya dapat diimplementasikan dengan baik karena sifat dari transmigran yang memiliki tingkat keuletan yang tinggi untuk memperbaiki hidupnya. Sekitar 39,5\% pembudidaya mempunyai pekerjaan sampingan lain yaitu menjadi buruh. Hal ini menandakan masih kurangnya pendapatan yang mereka hasilkan sebagai pembudidaya ikan nila.

Karakteristik responden tersebut dapat menjadi acuan bagi pemerintah untuk mengembangkan program-programusahabudidaya sekaligus mengenalkan berbagai diseminasi teknologi untuk kelompok budidaya. Perhatian dari pemerintah diharapkan dapat memperluas peluang usaha budidaya baik dari sisi produksi maupun strategi pemasarannya.

\section{Pola Perdagangan Komoditas Nila}

Struktur pasar dan perilaku untuk perdagangan ikan Nila konsumsi di Kabupaten Musi Rawas dapat dikelompokan menjadi 4 pelaku, antara lain:

\section{Pembudidaya}

Pendatang baru pada tingkat pembudidaya nila sangat terbuka luas. Hal ini dikarenakan teknologi budidaya cukup mudah dan modal yang relatif sedikit untuk memulai usaha budidaya. Pemasok benih pun saat ini sangat mudah untuk dijumpai. Pembeli dalam pasar juga cukup banyak walaupun saat ini kebanyakan hanya untuk konsumsi domestik. Dalam hal produk pengganti, justru ikan nila merupakan produk pengganti dari kakap merah yang berharga mahal. Namun, dengan tidak adanya hambatan untuk masuk dalam usaha ini menimbulkan persaingan dalam industri yang cukup ketat. Struktur pasar ikan Nila hidup di tingkat pembudidaya mendekati sifat persaingan sempurna. Hal ini berdasarkan ciriciri yang pasar persaingan sempurna, yaitu: (1) jumlah produsen yang sangat banyak dan tidak mempunyai kekuasaan secara individu untuk menentukan harga (pembudidaya sebagai price taker); (2) produk yang diperjualbelikan bersifat homogen; (3) pelaku bebas keluar masuk pasar; (4) pembeli dan penjual mengetahui satu sama lain dan mengetahui barang yang diperjualbelikan. Perilaku pelaku pembudidaya biasanya mengejar produksi sebanyak-banyaknya (kuantitas). (Arianto, 2008)

\section{Agen Luar Kota}

Struktur pasar yang terbentuk pada tingkat agen adalah oligopsoni. Oligopsoni, adalah keadaan

Tabel 3. Karakteristik Responden di Kabupaten Musi Rawas, Tahun 2012.

Table 3. Respondent Characteristics in the Musi Rawas Regency, 2012.

\begin{tabular}{clc}
\hline No & \multicolumn{1}{c}{ Karakteristik/Characteristics } & Persentase/Percentage (\%) \\
\hline 1 & Pengalaman Usaha/ Experience(1-5 tahun/year) & 42.9 \\
2 & Umur/Age (30-39 tahun/year) & 57.1 \\
3 & Suku/Tribe (Jawa/Java) & 85.7 \\
4 & Pekerjaan sampingan/Side job (Buruh/labor) & 57.1 \\
5 & Pendidikan/Education (SD/Elementary) & 39.5 \\
\hline
\end{tabular}

Sumber: Data primer diolah (2012) / Source: Primary data processed (2012) 
dimana dua atau lebih pelaku usaha menguasai penerimaan pasokan atau menjadi pembeli tunggal atas barang dan/atau jasa dalam suatu pasar komoditas (Oentoro, 2010). Masingmasing penjual mempunyai pengaruh terhadap harga, tetapi tidak melakukan perubahan harga yang mencolok. Di Pasar Jakabaring Kota Palembang, terdapat 3-5 agen ikan Nila. Agen tersebut yang menentukan harga ikan Nila. Salah satu cara untuk menguasai pasar adalah dengan memberikan kemudahankemudahan terhadap pembelinya dalam hal ini adalah pengecer ikan di pasar. Kemudahankemudahan tersebut seperti cara pembayaran yang ringan dimana pembeli boleh membayar produk yang diambil setelah produk tersebut laku terjual. Hal ini selain memperkuat agen dalam pasar juga membuat agen semakin berdaya dalam menentukan harga.

\section{Pedagang Besar /Pengepul Lokal}

Sama halnya dengan Agen, di tingkat pengepul atau pedagang besar lokal juga terbentuk struktur pasar oligopsoni karena jumlah pedagang besar. Pengepul mempunyai andil untuk menentukan harga ikan Nila di tingkat pembudidaya. Tetapi juga tidak dapat menentukan harga yang terlalu berbeda dengan harga pasar. Untuk mempertahankan atau menguasai pasar, pengepul memberikan bantuan kepada pembudidaya. Bantuan tersebut seperi pemberian modal kerja (benih dan pakan), dengan demikian terjalin ikatan patron-client antara pengepul dan pembudidaya.

\section{Pengecer}

Di tingkat pengecer, struktur pasar yang terbentukadalah pasar persaingan monopolistik, dimana jumlah penjual agak banyak namun masing-masing mempunyai sedikit pengaruh terhadap pasar dan produk yang diperjual belikan tidak homogen. Dalam hal ini, pengecer ikan nila di pasar-pasar yang menjadi lokasi penelitian berjumlah cukup banyak, kurang lebih 10 pengecer yang ditemui. Walaupun produk yang diperjualbelikan adalah ikan nila, tetapi ada perbedaan lokasi tempat berjualan sehingga masing-masing produk menjadi berbeda antara pengecer satu dengan yang lainnya. Pengecer yang berada di dalam lokasi pasar akan menjual produknya lebih murah dibandingkan dengan harga yang ditawarkan pengecer yang berlokasi di pintu masuk pasar. Hal ini sebagai upaya untuk menguasai pasar dan menarik pembeli.

Tabel 4. Struktur Pasar Produsen Nila di Kabupaten Musi Rawas, Sumatera Selatan, Tahun 2012. Table 4. Market Structure of Tilapia Producer in the Musi Rawas Regency, South Sumatera, 2012.

\begin{tabular}{|c|c|c|c|c|}
\hline $\begin{array}{l}\text { Segementasi/ } \\
\text { Segmentation }\end{array}$ & $\begin{array}{l}\text { Jumlah pelaku/ } \\
\text { Number of Actor }\end{array}$ & $\begin{array}{l}\text { Hambatan Masuk/ } \\
\text { Barrier to Entry }\end{array}$ & $\begin{array}{c}\text { Diferensiasi } \\
\text { Produk/Product } \\
\text { Differentiation }\end{array}$ & $\begin{array}{l}\text { Struktur Pasarl } \\
\text { Market Structure }\end{array}$ \\
\hline Pembudidaya/Farmer & Banyak/Many & $\begin{array}{l}\text { Rendah, teknologi } \\
\text { mudah dan modal } \\
\text { relatif kecil/Low, easy } \\
\text { technology and small } \\
\text { capital }\end{array}$ & Tidak ada/None & $\begin{array}{l}\text { Persaingan sempurna/ } \\
\text { Competitive rivalry }\end{array}$ \\
\hline $\begin{array}{l}\text { Agen luar kota/ } \\
\text { outside trader }\end{array}$ & Sedikit/Few & $\begin{array}{l}\text { Tinggi, modal yang } \\
\text { besar/High, huge } \\
\text { capital }\end{array}$ & Tidak ada/None & Oligopsoni/Oligopsony \\
\hline $\begin{array}{l}\text { Pedagang lokal/ } \\
\text { Local trader }\end{array}$ & Sedikit/Few & $\begin{array}{l}\text { Tinggi, modal yang } \\
\text { besar/ High, huge } \\
\text { capital }\end{array}$ & Tidak ada/None & Oligopsoni/Oligopsony \\
\hline Pengecer/Retailer & $\begin{array}{l}\text { Agak banyak/ } \\
\text { Moderate }\end{array}$ & Rendah/Low & Tidak Ada/None & $\begin{array}{l}\text { Persaingan monopolistik/ } \\
\text { Monopolistic rivalry }\end{array}$ \\
\hline $\begin{array}{l}\text { Pengolahan ikan } \\
\text { asap/Smoked fish } \\
\text { processing }\end{array}$ & Sedikit/Few & $\begin{array}{l}\text { Cenderung rendah, } \\
\text { namun pasar masih } \\
\text { terbatas/Moderate } \\
\text { low, limited market }\end{array}$ & Tidak ada/None & Oligopsoni/Oligopsony \\
\hline $\begin{array}{l}\text { Pengolahan ikan } \\
\text { asin/Salt fish } \\
\text { processing }\end{array}$ & $\begin{array}{l}\text { Hanya satu/Only } \\
\text { one }\end{array}$ & $\begin{array}{l}\text { Cenderung rendah, } \\
\text { namun pasar masih } \\
\text { terbatas/Moderate } \\
\text { low, limited market }\end{array}$ & Tidak ada/None & Monopsoni/Monopsony \\
\hline
\end{tabular}




\section{Pengolah}

Di tingkat pengolah, struktur pasar yang terbentuk untuk pengolah ikan asin adalah pasar monopsoni, dimana jumlah pembeli bahan baku ikan segar hanya satu dan dapat memberikan pengaruh terhadap harga pasar. Sedangkan untuk pengolah ikan asap, struktur yang terbentuk adalah oligopsoni dimana terdapat setidaknya 3 pembeli bahan baku ikan segar yang mampu memberikan pengaruh terhadap harga pasar.

\section{Pemasaran Ikan Nila}

Berdasarkan hasil pengamatan lapang, telah diperoleh informasi mengenai jenis produk akhir komoditas Nila yang diterima oleh konsumen dan saluran pemasarannya. Untuk produk akhir, yang dipasarkan adalah nila segar, ikan asap, ikan asin dan masakan nila. Berdasarkan hasil penelitian, terdapat 6 saluran pemasaran ikan Nila untuk konsumsi, (Tabel 5).

Tujuan pemasaran ikan nila segar dan masakan ikan nila yang disalurkan oleh para pengecer tersebar di daerah Propinsi Sumatera Selatan. Untuk olahan Ikan asap yang dipasarkan langsung oleh pengolah banyak dijual pada pasarpasar lokal di Kabupaten Musi Rawas. Sedangkan untuk produk akhir berupa olahan ikan asin, biasanya dipasarkan oleh pengolah ke pasar di daerah Bogor (Gambar 2).

Dari rantai pasok tersebut dapat terdeteksi bahwa untuk komoditas ikan nila di Kabupaten Musi Rawas setidaknya memiliki 6 saluran pemasaran. Dari saluran pemasaran ini setidaknya dapat dilihat margin pemasaran dan keuntungan yang diperoleh pembudidaya. Jika margin pemasarannya terlalu besar maka dapat diduga saluran pemasarannya tidak efektif. Selain komponen biaya pemasaran, margin pemasaran juga sangat ditentukan oleh harga beli para pelaku pasar dari produsen terkait komoditas yang diperjualbelikan. Berikut adalah tabel gambaran margin pemasaran di setiap saluran pemasaran (Tabel 6).

Untuk saluran 5 dan 6, pembudidaya menyalurkan langsung hasil panen ikan nila ke masing-masing pengolah, tidak dapat dilakukan penghitungan terhadap margin pemasarannya karena sudah terjadi proses perubahan bentuk dari ikan segar menjadi produk olahan. Tetapi bisa dilihat keuntungannya sebesar Rp. 1.343,- jika dijual ke pengolah ikan asin dan sebesar Rp. 4.843,- jika dijual ke pengolah ikan asap. Untuk pengolah ikan asin dihargai rendah karena biasanya yang diambil adalah ikan-ikan berukuran kecil.

Tabel 5. Saluran Pemasaran dan Produk Akhir Komoditas Nila di Kabupaten Musi Rawas, Sumatera Selatan.

Tabel 5. Tilapia's Channel Marketing and Its End Product in the Musi Rawas Regency, South Sumatera.

\begin{tabular}{|c|c|c|c|c|c|c|}
\hline $\begin{array}{l}\text { Saluran/ } \\
\text { Channel }\end{array}$ & $\begin{array}{c}\text { Rantai } 1 / \\
\text { Chain } 1\end{array}$ & $\begin{array}{c}\text { Rantai 2/ } \\
\text { Chain } 2\end{array}$ & $\begin{array}{c}\text { Rantai 3/ } \\
\text { Chain } 3\end{array}$ & $\begin{array}{c}\text { Rantai 4/ } \\
\text { Chain } 4\end{array}$ & $\begin{array}{c}\text { Rantai 5/ } \\
\text { Chain } 5\end{array}$ & $\begin{array}{c}\text { Produk } \\
\text { Akhir/ End } \\
\text { product }\end{array}$ \\
\hline 1 & $\begin{array}{l}\text { Pembudidaya/ } \\
\text { Farmer }\end{array}$ & $\begin{array}{l}\text { Pedagang besar } \\
\text { Lokal/Local } \\
\text { wholesaler }\end{array}$ & $\begin{array}{l}\text { Pedagang } \\
\text { Pengecer/ } \\
\text { Retail trader }\end{array}$ & $\begin{array}{l}\text { Konsumen } \\
\text { akhir/End } \\
\text { consumer }\end{array}$ & & $\begin{array}{l}\text { Ikan segar/ } \\
\text { Fresh fish }\end{array}$ \\
\hline 2 & $\begin{array}{l}\text { Pembudidaya/ } \\
\text { Farmer }\end{array}$ & $\begin{array}{l}\text { Pedagang Besar } \\
\text { Lokal/ Local } \\
\text { wholesaler }\end{array}$ & $\begin{array}{l}\text { Agen Luar } \\
\text { Kota/ Agent } \\
\text { from other } \\
\text { region }\end{array}$ & $\begin{array}{l}\text { Pedagang } \\
\text { pengecer/ } \\
\text { Retail trader }\end{array}$ & $\begin{array}{l}\text { Konsumen } \\
\text { akhir/ End } \\
\text { consumen }\end{array}$ & $\begin{array}{l}\text { Ikan Segar/ } \\
\text { Fresh fish }\end{array}$ \\
\hline 3 & $\begin{array}{l}\text { Pembudidaya/ } \\
\text { Farmer }\end{array}$ & $\begin{array}{l}\text { Agen di Luar kota/ } \\
\text { Agent from other } \\
\text { region }\end{array}$ & $\begin{array}{l}\text { Pedagang } \\
\text { pengecer/ } \\
\text { Retail trader }\end{array}$ & $\begin{array}{l}\text { Konsumen } \\
\text { akhir/End } \\
\text { consumer }\end{array}$ & & $\begin{array}{l}\text { Ikan Segar/ } \\
\text { Fresh fish }\end{array}$ \\
\hline 4 & $\begin{array}{l}\text { Pembudidaya/ } \\
\text { Farmer }\end{array}$ & $\begin{array}{l}\text { Pedagang } \\
\text { Pengecer/ Retail } \\
\text { trader }\end{array}$ & $\begin{array}{l}\text { Pengecer } \\
\text { Restoran/ } \\
\text { Restaurant }\end{array}$ & $\begin{array}{l}\text { Konsumen } \\
\text { Akhir/End } \\
\text { consumer }\end{array}$ & & $\begin{array}{l}\text { Masakan } \\
\text { nila/ Tilapia } \\
\text { food }\end{array}$ \\
\hline 5 & $\begin{array}{l}\text { Pembudidaya/ } \\
\text { Farmer }\end{array}$ & $\begin{array}{l}\text { Pengolah ikan/ Fish } \\
\text { processor }\end{array}$ & $\begin{array}{l}\text { Pedagang } \\
\text { pengecer/ } \\
\text { Retail trader }\end{array}$ & $\begin{array}{l}\text { Konsumen } \\
\text { akhir/End } \\
\text { consumer }\end{array}$ & & $\begin{array}{l}\text { Ikan asin/ } \\
\text { Salted fish }\end{array}$ \\
\hline 6 & $\begin{array}{l}\text { Pembudidaya/ } \\
\text { Farmer }\end{array}$ & $\begin{array}{l}\text { Pengolah ikan/ Fish } \\
\text { processor }\end{array}$ & $\begin{array}{l}\text { Pedagang } \\
\text { pengecer/ } \\
\text { Retailer }\end{array}$ & $\begin{array}{l}\text { Konsumen } \\
\text { akhir/End } \\
\text { consumer }\end{array}$ & & $\begin{array}{l}\text { Ikan asap / } \\
\text { Smoked fish }\end{array}$ \\
\hline
\end{tabular}

Sumber: Data primer diolah (2012) / Source: Primary data processed (2012) 


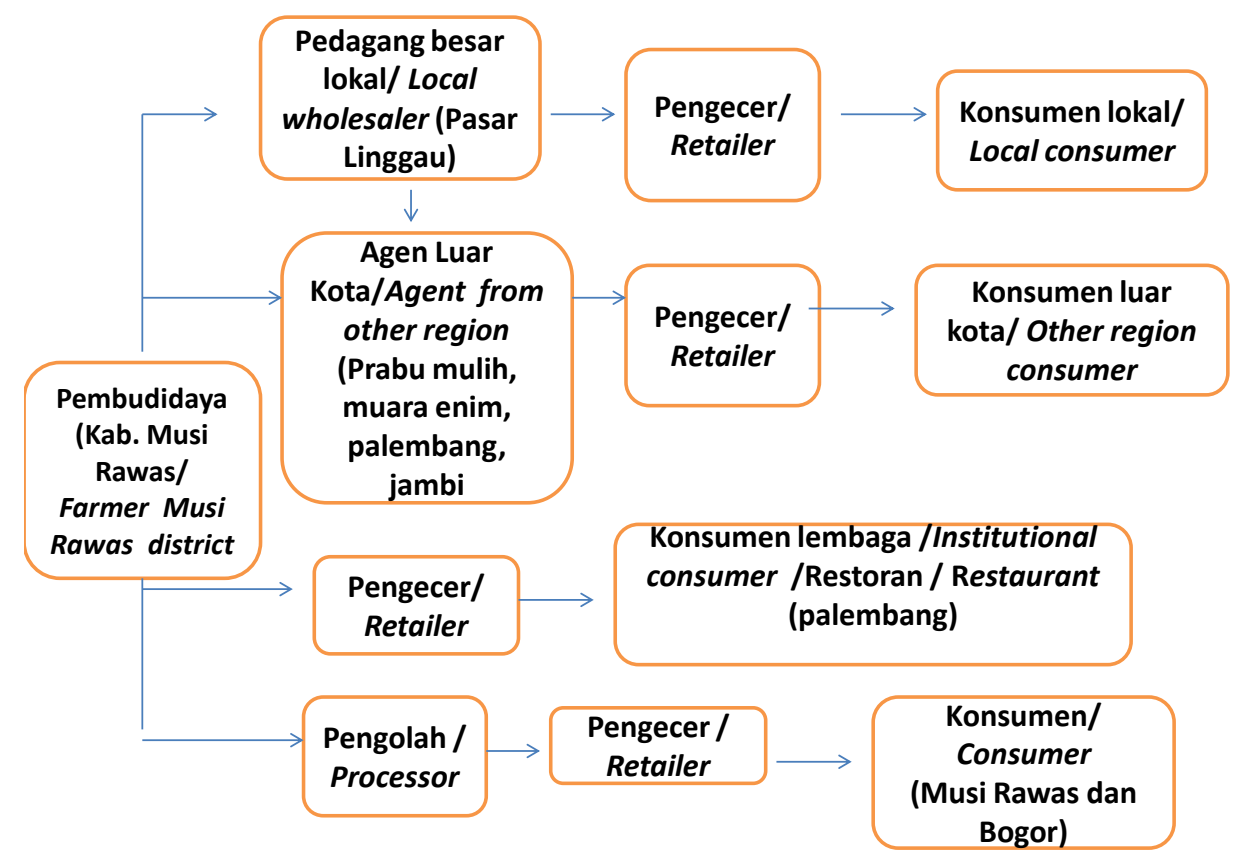

Gambar 2. Rantai Pasok Pemasaran Ikan Nilai di Kabupaten Musi RawasTahun 2012.

Figure 2. Tilapia Marketing Supply Chain in the Musi Rawas Regency, 2012.

Sumber: Data primer diolah (2012) / Source: Primary data processed (2012)

Tabel 6. Harga Beli Awal Ikan Nila dan Margin Pemasaran Pedagang Besar Lokal, Agen Luar Kota, Pedagang Pengecer di Kabupaten Musi Rawas, Sumatera Selatan, 2012.

Table 6. Tilapia's Buyer Price and Local Wholesaler, Agent from Other Region, Retail Trader Marketing Margin in the Musi Rawas Region, South Sumatera, 2012.

\begin{tabular}{|c|c|c|c|c|c|c|}
\hline $\begin{array}{l}\text { Saluran/ } \\
\text { Channel }\end{array}$ & $\begin{array}{l}\text { Harga Beli } \\
\text { Ikan Dari } \\
\text { Pembudidaya/ } \\
\text { Buyer Fish } \\
\text { Price from } \\
\text { Farmer } \\
\text { (Rp/Kg) }\end{array}$ & $\begin{array}{c}\text { Margin } \\
\text { Pemasaran } \\
\text { Pedagang } \\
\text { Besar Lokal/ } \\
\text { Marketing } \\
\text { Margin Local } \\
\text { Trader } \\
\text { (Rp/Kg) }\end{array}$ & $\begin{array}{c}\text { Margin } \\
\text { Pemasaran } \\
\text { Agen Luar Kota/ } \\
\text { Outside Agent's } \\
\text { Marketing } \\
\text { Margin } \\
\text { (Rp/Kg) }\end{array}$ & $\begin{array}{l}\text { Margin Pemasaran } \\
\text { Pedagang } \\
\text { Pengecer/ } \\
\text { Marketing Margin } \\
\text { for Retail Trader } \\
\text { (Rp/Kg) }\end{array}$ & $\begin{array}{c}\text { Total } \\
\text { Margin } \\
\text { Pemasaran/ } \\
\text { Total Marketing } \\
\text { Margin } \\
\text { (Rp/Kg) }\end{array}$ & $\begin{array}{l}\text { Keuntungan } \\
\text { Pembudidaya } \\
\text { dari Penjualan/ } \\
\text { Farmer Profit } \\
\text { From Sales } \\
\text { (Rp/Kg) }\end{array}$ \\
\hline 1 & 16,500 & 2,250 & - & 5,250 & 7,500 & 4,843 \\
\hline 2 & 16,500 & 2,250 & 2,250 & 4,000 & 8,500 & 4,843 \\
\hline 3 & 18,000 & - & 3,000 & 4,000 & 7,000 & 6,343 \\
\hline 4 & 21,000 & - & - & 3,000 & 3,000 & 9,343 \\
\hline 5 & 13,000 & - & - & - & - & 1,343 \\
\hline 6 & 16,500 & - & - & - & - & 4,843 \\
\hline
\end{tabular}

Sumber: Data primer diolah (2012) / Source: Primary data processed (2012)

Dari tabel di atas dapat dilihat pula rantai pemasaran terpendek dengan margin paling rendah hanya sebesar Rp. 3.000,- adalah saluran 4. Saluran yang menghubungkan antara pembudidaya dan konsumen lembaga/restoran juga ternyata memberikan keuntungan terbesar bagi pembudidaya yaitu sebesar Rp. 9.343,-Namun, persyaratan ikan nila yang dapat dijual untuk kebutuhan restoran tidaklah mudah. Ukuran nila yang diminta di atas 400 gram, sedangkan yang para pembudidaya dalam jangka watu 4 bulan pemeliharaan biasanya ukuran ikan yang dihasil 3-6 ekor $/ \mathrm{kg}$ atau paling besar 350 gram. Hal ini tentunya harus meningkatkan usaha dari pembudidaya agar bisa menghasilkan ikan yang ukurannya sesuai baik dengan pemberian 
pakan yang ditingkatkan maupun waktu panen yang lebih lama. Jika pembudidaya berani untuk mengklasifikasikan segmentasi usahanya untuk masing-masing kebutuhan pasar, usaha ikan nila ini akan sangat menjanjikan.

Permintaan untuk kebutuhan restoran yang masih sedikit dan persyaratan ukuran yang diinginkan membuat pembudidaya harus menjual hasil panennya ke pelaku pemasaran lainnya. Dari tabel dapat terlihat bahwa saluran 3 memiliki margin pemasaran terkecil dan keuntungan terbesar jka dibandingkan dengan saluran 1 dan 2. Pada saluran 3, pembudidaya langsung memasarkan hasil panennya melalui agen luar kota. Namun, pada implementasinya, menjual ikan ke agen luar kota merupakan pilihan jika ikan hasil panen pembudidaya tidak habis dibeli oleh pedagang besar lokal. Padahal pedagang besar lokal membeli dengan harga yang rendah yaitu sebesar Rp. 16.500,- saja. Hal ini dikarenakan terdapat hubungan patron-client antara pedagang besar lokal dengan pembudidaya terkait permodalan usaha. Banyak pembudidaya yang meminjam uang ke pedagang besar lokal dengan perjanjian harus menjual hasil panennya ke mereka dengan harga yang ditentukan pedagang. Dengan demikian, pembudidaya selalu menjadi price taker tanpa ada posisi tawar dengan pedagang.

Untuk mengatasi masalah pembudidaya sebagai price taker, hubungan patron-client harus dapat diputus. Pembudidaya harus dapat mandiri mengenai modalnya atau setidaknya bergantung pada pihak yang tidak akan mempengaruhi keputusan harga jual beli ikan seperti misalnya bank atau lembaga keuangan lainnya. Jika pembudidaya tidak memiliki hubungan patron cliet terkait permodalan dengan pedagang besar lokal, maka pembudidaya memiliki pilihan pasar yang lebih luas dan pedagang pasar lokal akan secara alami mengikuti harga yang diberikan oleh agen luar kota. Perluasan pasar juga akan sangat berarti untuk mengatasi terjadi lonjakan produksi akibat panen secara bersamaan.

\section{KESIMPULAN DAN IMPLIKASI KEBIJAKAN}

\section{Kesimpulan}

Dari pengamatan usaha budidaya, produksi di Kabupaten Musi Rawas masih dapat ditingkatkan. Hal ini disebabkan oleh mayoritas pembudidaya sebanyak 57,9 \% berumur produktif dengan tingkat pendidikan minimal SD. Hal ini memungkinkan terus dilakukannya peningkatan produksi melalui pengenalan teknologi. Selain itu peningkatan ini juga didukung sumber pengairan yang banyak di sepanjang Kabupaten. Karakteristik pembudidaya di Musi Rawas juga termasuk mudah untuk menerima pengenalan teknologi yang berkaitan dengan kegiatan pemasaran seperti informasi pasar.

Dilihat dari struktur industri, peluang juga masih terbuka lebar bagi yang ingin berusaha di bidang pengolahan ikan nila mengingat jumlah pelaku yang masih sedikit dan peluang untuk usaha budidaya ikan nila masih terbuka lebar karena teknologi budidaya yang cukup mudah dan modal yang relatif sedikit. Namun sistem pemasaran yang ada belum memberikan keuntungan optimal bagi pembudidaya ikan. Banyak pembudidaya yang dirugikan akibat lemahnya posisi tawar mereka. Selain itu, kesempatan usaha juga masih terbuka untuk pelaku pasar karena jumlah pelaku pasar yang sedikit jika dibandingkan dengan pasokan ikan.

Dilihat dari tujuan pemasaran, pasar masih terbatas pada daerah sekitar (lokal), belum ada aktifitas ekspor. Tujuan pemasarannya untuk nila hidup, masakan ikan nila dan ikan asap adalah di sekitar Kabupaten Prabumulih, Kota Linggau, Kabupaten Muara Enim, Kota Palembang dan ada pula yang didistribusikan ke Propinsi Jambi. Sedangkan untuk ikan asin nila dipasarkan hingga ke Bogor.

Analisis menunjukkan, saluran pemasaran terbagi menjadi 6 saluran pemasaran. Saluran ini mengalirkan produk dengan pelaku pasar: pedagang besar lokal, agen besar luar kota, pengecer dan pengolah. Walaupun jumlah saluran pemasarannya banyak, pemain yang ada di dalamnya khususnya pada pedagang baik lokal dan luar kota sangatlah sedikit. Begitupun dengan jumlah pengolah. Ditambah lagi dengan adanya hubungan patron client antara pedagang besar lokal dan pembudidaya sehingga pembudidaya tidak leluasa memasarkan produknya ke saluran lain sebelum ditawarkan terlebih dahulu ke pedagang lokal. Hal ini dikhawatirkan akan menyumbat saluran pemasaran dan pembudidaya terus berada di posisi tawar yang lemah.

Untuk saluran pemasaran yang paling menguntungkan adalah jika pembudidaya menjual produknya ke pedagang pengecer untuk kebutuhan 
restoran. Harga yang akan didapatkan tinggi namun perlu diingat biasanya jumlah yang dibeli tidak terlalu banyak sesuai dengan perkembangan permintaan dari sektor restoran dan ukuran yang lebih besar. Dalam jumlah besar, pembudidaya dapat memasarkan hasil panennya ke agen luar kota dengan margin pemasaran terendah dan untung tertinggi jika dibandingkan dengan menjual hasil ke pedagang besar lokal.

\section{Implikasi Kebijakan}

1. Untuk mengatasi kelemahan posisi dari pembudidaya, khususnya dalam hal harga, hubungan patron-client antara pembudidaya dan pedagang besar lokal harus dapat dihilangkan. Pemerintah dapat memberikan akses permodalan atau membantu untuk menguatkan kelembagaan finansial kelompok untuk melepas pola ketergantungan pembudidaya dan pedagang besar.

2. Pembudidaya harus dilengkapi dengan market information yang baik untuk pengembangan jaringan pasar, sehingga pembudidaya dihadapkan pada banyak opsi pembeli.

3. Pembudidaya baiknya melakukan segmentasi produk sehingga dapat dipasarkan pada masing-masing pelaku pasar sesuai dengan persyaratan yang diinginkan

4. Dikarenakan keuntungan yang diperoleh dari saluran pemasaran untuk tujuan konsumen lembaga (restoran ) cukup tinggi, maka dapat diciptakan bentuk-bentuk market creativity untuk membuat masyarakat menyukai ikan nila. Ikan nila dapat diperkenalkan bukan hanya untuk kebutuhan restoran, tapi juga menu di hotel ataupun catering sehingga permintaan ikan nila akan terus meningkat

\section{DAFTAR PUSTAKA}

Anwar, I.M. 1994. Dasar-Dasar Marketing. Penerbit Alumni Bandung, Bandung.

Arianto, E. 2008. Mengukur Struktur Industri (Pasar). http://strategika.wordpress.com/ 2008/08/04/mengukur-struktur-industri/ (Diakses tanggal 25 Februari 2013).

Dahl \& J. W. Hammond. 1977. Market and Price Analysis: agricultural industries. New York: Mc. Graw Hill Book Company.

Dardiani \& R. S. Intan. 2010. Mata Diklat 7 Manajemen Pemasaran. Pusat Pengembangan dan Pemberdayaan Pendidik dan Tenaga Kependidikan Pertanian.

Dinas Kelautan dan Perikanan Propinsi Sumatera Selatan. 2010. Profil Perikanan Budidaya 2009. Sumatera Selatan.

Dinas Kelautan dan Perikanan Propinsi Sumatera Selatan. 2011. Profil Perikanan Budidaya 2011.Sumatera Selatan.

Iriana, D. W. 2009. Kapan Menjadi Pemasok Utama. (http://www.agrina-online.comredesign2. php?rid=7\&aid=1994. diunduh tanggal 7 januari 2013).

Kementerian Kelautan dan Perikanan. 2012 Statistik Perikanan Budidaya Indonesia 2011. Jakarta: Direktorat Perbenihan.

Kementerian Kelautan dan Perikanan. 2011. Statistik Perikanan Budidaya Indonesia 2010. Jakarta: Direktorat Jenderal Perikanan Budidaya.

Khairuman \& Amri. 2011. 2,5 Bulan Panen Ikan Nila. Jakarta: PT. Agromedia Pustaka.

Pondaag, I.S. 2010. Budidaya Ikan Nila..(http:// epetani.deptan.go.id/budidaya/budidayaikan-nila-98 (Diakses tanggal 22 Oktober 2013).

Oentoro, D. 2010. Manajemen Pemasaran Modern. Yogyakarta: Laksbang Pressindo. 